\title{
STRES KERJA GURU SAAT PANDEMI COVID-19 DITINJAU DARI KOMPENSASI DAN LINGKUNGAN KERJA
}

\author{
Tri Anita ${ }^{1(*)}$, Sumaryati Tjitrosumarto $^{2}$, J. Sabas Setyohadi $^{3}$ \\ Universitas Indraprasta PGRI, Jakarta, Indonesia ${ }^{123}$ \\ itatrianita18@gmail.com ${ }^{1}$
}

$\begin{array}{ll}\text { Received: } & \text { 01 Februari } 2021 \\ \text { Revised: } & \text { 24 Februari } 2021 \\ \text { Accepted: } & \text { 13 Maret } 2021\end{array}$

\begin{abstract}
Pandemi Covid-19 yang melanda dunia saat ini menimbulkan kecemasan, kekhawatiran dan kepanikan kepada seluruh masyarakat termasuk para guru. Guru Sekolah Menengah Kejuruan yang harus mengajar lebih banyak praktek dibandingkan materi terkendala untuk melakukan praktek karena pandemic Covid-19. Tujuan penelitian untuk mengetahui stress kerja guru SMK yang ditinjau dari kompensasi dan lingkungan kerja. Penelitian dilakukan pada 4 SMKN di Jakarta Timur dengan jumlah sampel 115 orang guru. Metode penelitian adalah kuantitatif dengan teknik analisis regresi berganda. Hasil penelitian menunjukkan secara simultan terdapat pengaruh kompensasi dan lingkungan kerja terhadap stress kerja; kompensasi berpengaruh terhadap stress kerja; terdapat pengaruh lingkungan kerja terhadap stress kerja. Kontribusi parsial kompensasi terhadap stress kerja sebesar 28,6\% dan kontribusi lingkungan kerja terhadap stress kerja sebesar $19,7 \%$. Total kontribusi kompensasi dan lingkungan kerja terhadap stress kerja sebesar 38\%. Implikasinya bagi pihak manajemen sekolah harus tetap memberikan kompensasi yang layak bagi para guru dan menciptakan lingkungan kerja mulai mengadopsi teknologi untuk mengurangi stress kerja guru saat Pandemi Covid-19.
\end{abstract}

Keywords: Covid-19; Stres Kerja; kompensasi; Lingkungan Kerja; SMK

(*) Corresponding Author: Anita, itatrianita18@gmail.com

How to Cite: Anita, T., Tjitrosumarto, S., \& Setyohadi, J. S. (2021). Stres Kerja Guru Saat Pandemi Covid19 Ditinjau Dari Kompensasi Dan Lingkungan Kerja. Research and Development Journal of Education, 7 (1), 146-157.

\section{INTRODUCTION}

Perhatian terhadap sumber daya manusia sangatlah penting guna menghasilkan output seperti yang diharapkan dalam rangka mencapai visi dan misi serta tujuan organisasi. Guru sebagai faktor penentu dalam keberhasilan pendidikan perlu diperhatikan kondisi fisik dan psikisnya pada masa pandemi Covid-19 saat ini (Ratten \& Jones, 2020). Berdasarkan hal tersebut diperhatikan peraturan yang berkaitan dengan keberadaan sumber daya manusia dalam organisasi yang sedikit banyak menentukan tercapai tidaknya tujuan organisasi. Perkembangan teknologi yang sangat pesat ditandai dengan munculnya zaman Revolusi Industri 4.0 membawa perubahan dalam upaya organisasi mengelola sumberdaya manusia. Lingkungan kerja yang tidak pasti, turbulensi dalam pekerjaan dan ketidakpastian merupakan ciri era yang terjadi pada saat ini (L. Anderson, Mason, Hibbert, \& Rivers, 2017). Jika tetap melakukan adapatasi maka akan hilang tergerus oleh arus perubahan yang cepat.

Apabila penyesuaian ini gagal atau salah, maka akan mengakibatkan terjadinya stres di tempat kerja. Stres bukanlah sekedar kondisi psikologis yang terganggu, akan tetapi lebih kepada bagaimana para karyawan merespon dan sikap dalam bekerja dalam mencapai tujuan (Hussain \& Chaman, 2016). Ketidakmampuan dalam beradaptasi inilah 
yang akan menimbulkan frustrasi, konflik, gelisah, dan rasa bersalah. Dampak dari stres yang muncul pada individu dapat beragam. Hal ini tergantung pada kekuatan konsep diri yang menentukan terhadap stress kerja yang dapat muncul. Karyawan yang stres akan sulit berkonsentrasi yang dapat berdampak negatif menghambat pekerjaan bahkan dapat menurunkan komitmen individu terhadap organisasi (Paramita, Putra, \& Handaru, 2016). Selain itu stress juga dapat menimbulkan persepsi yang negatif terhadap pekerjaannya (Macintyre et al., 2019).

Perubahan karena Revolusi Industri 4.0 dipercepat dengan adanya pandemic Covid-19 yang tengah melanda dunia saat ini. Pandemic yang diawali muncul di Kota China Desember 2019 telah memaksa berbagai elemen organisasi, ekonomi termasuk Pendidikan berubah dengan lebih tergantung kepada teknologi (Ratten \& Jones, 2020). Hal ini tentu saja akan menambah beban guru dalam mengajar karena harus memikirkan cara terbaik untuk mengajar ditengah Pandemi Covid-19. Kemampuan guru untuk menggunakan teknologi dalam mengajar seperti menggunakan media social ternyata merupakan tantangan bagi para guru karena cukup banyak guru yang belum dapat memanfaatkan social media sehingga siswa kurang faham akan materi yang disampaikan (Chaturvedi, Kumar Vishwakarma, \& Nidhi, 2020).

Hal ini tentu saja dapat menjadi sumber stress baru bagi guru. Stres kerja merupakan respon psikologis dan emosional yang tidak terkontrol muncul karena berinteraksi dengan lingkungan fisik dan non fisik. Sehingga seorang pegawai harus dapat mengontrol respon dalam hal psikologis dan emosial dengan baik supaya tidak menjadi stres (Daft, 2008). Penyebab stres merujuk kepada karakteristik pekerjaan, kegiatan atau situasi yang dapat menimbulkan stress, dan kondisi psikologis serta respon individu terhadap stress (Hurrell, Nelson \& Simmons dalam (N. Anderson, Ones, Sinangil, \& Viswesvaran, 2012). Salah satu upaya untuk mengendalikan stressor adalah memperhatikan lingkungan kerja dan kompensasi yang didapatkan. Hal ini disebabkan karena stres kerja itu bisa diakibatkan karena pengaruh gaji yang terlalu kecil diterima karyawan (Nasution, 2017).

Salah satu cara organisasi untuk meningkatkan kinerja organisasi adalah dengan membuat pegawai bekerja dengan maksimal. Kompensasi karyawan adalah salah satu kompnen utama hubungan kerja yang sering dapat menimbulkan masalah dalam hubungan dunia kerja dalam menciptakan performa perusahaan atau organisasi yang maksimal. Perihal kompensasi, misalnya gaji selalu menjadi perhatian pengelola perusahaan, pegawai, dan pemerintah (Sunarsi, 2018).

Pandemic Covid-19 yang menjadi salah satu sumber stress bagi guru dapat dikategorikan sebagai factor lingkungan. Lingkungan kerja merujuk kepada hal-hal yang berkaitan dengan satuan pekerjaan, desain pekerjaan, sarana dan prasarana, gaya kepemimpinan, jaringan kerjasama, dan imbalan (Widodo, 2010). Menurut Powell, Guadagno, \& Cassematis (2013) controlling the negative influence of work stress on investigative interviewers requires (at least in the first instance) modification of the work environment rather than attempts to limit exposure to case material through maximum tenure and forced job rotation which undermine opportunities for specialisation.

Because the great majority of stimuli in the work environment do not require adaptation, they are not really potential stress sources (Gibson, Ivancevich, James H. Donnelly, \& Konopaske, 2012). Lingkungan kerja menstimuli dari stres kerja. Jadi lingkungan kerja butuh perhatian ekstra untuk mengamati penyebab dari stres kerja. Temuan tersebut dikuatkan oleh N. Anderson et al., (2012) yang menyatakan occupational stress is a growing problem that results in substantial cost to individual employees and work organizations around the globe. Jadi stres juga tumbuh karena permasalahan antara gaji (pembiayaan) yang diterima oleh pegawai dengan tuntutan yang diberikan oleh organisasi terhadap pegawai tersebut. 
Kondisi pandemi Covid-19 menimbulkan stress yang tinggi terhadap guru dan cenderung menjadi burnout karena lingkungan kerja yang serba digital dan pembelajaran dalam jaringan (Ansley et al., 2021). Beberapa literatur menunjukkan stres kerja guru pada masa pandemi Covid 19 mayoritas disebabkan karena lingkungan, self-efficacy dan social support (Cappe, Poirier, Engelberg, \& Boujut, 2021; Vertanen-Greis, Loyttyniemi, Uitti, \& Putus, 2020). Belum ada hasil literatur yang melihat stres kerja guru dipengaruhi oleh kompensasi. Ketika masa pandemi Covid 19 terjadi resesi ekonomi yang melanda seluruh dunia yang mengakibatkan perekonomian turun yang berimbas kepada pemotongan gaji dan insentif pada seluruh pegawai termasuk para guru. Maka dari itu perlu adanya suatu kajian yang melihat stres kerja guru pada masa pandemi Covid 19 dari aspek kompensasi dan lingkungan kerja.

\section{LITERATURE REVIEW}

\section{Stres Kerja Guru}

Karyawan dapat menjadi stres karena karyawan sebagian besar waktunya dihabiskan di tempat kerja dengan rutinitas pekerjaan yang sama. Oleh karena itu organisasi perlu mengenali dan memberikan umpan balik berupa kompensasi kepada karyawan (Irawati, 2018). Bertambah tingginya respons umpan balik dalam bentuk kompensasi yang diberikan organisasi terhadap karyawan, maka semakin bahagia pula karyawan bekerja karena kompensasi merupakan bentuk penghargaan untuk karyawan atau balas jasa atas andil yang mereka berikan kepada organisasinya (Handaru, Utomo, \& Sudiarditha, 2013). Menurut Umar dalam Sunarsi (2018) kompensasi dapat diartikan sebagai suatu hal yang didapatkan oleh karyawan sebagai imbal balik untuk kerja mereka.

Menurut Luthans (2011) dimensi dari stress kerja yaitu: (1) Extraorganizational Stressors adalah stress dari luar organsiasi yang mempengaruhi kinerja karyawan yang terdiri atas perubahan teknologi, globalisasi, keluarga, pindah tugas, kondisi ekonomi dan finansial, suku dan ras, kondisi tempat tinggal; (2) Organizational Stressors, stress yang berasal dari dalam organisasi terkait dengan tugas dan tanggung jawab karyawan yang terdiri atas indikator tugas dikantor, konflik dan beban kerja, keamanan kerja, konflik sesama rekan kerja, lingkungan yang tidak menentu; (3) Group Stressors, stress yang berasal dari kelompok formal dan non formal yang dapat memicu konflik yang terdiri atas rasa keterikatan kelompok yang lemah dan kurangnya dukungan kelompok; (4) Individual Stressors, stress dari individu masing-masing karyawan yang terdiri atas indikator kematangan kepribadian dan pengendalian diri.

\section{Kompensasi}

Kompensasi untuk karyawan bertujuan mendorong kinerja karyawan dan sebagai penentu seberapa besar kompensasi bagi setiap karyawan. Pendapat tersebut memperlihatkan bahwa kontribusi yang diberikan oleh pegawai agar mendapatkan kompensasi harus membuat kemajuan bagi organisasi. Perusahaan memberikan kompensasi memiliki tujuan untuk meningkatkan kinerja karyawan lebih baik lagi.

Pemberian kompensasi yang baik harus menggunakan manajemen kompensasi yang tepat. Manajemen kompensasi adalah salah satu fungsi penting dalam manajemen sumber daya manusia (Sari, 2009). Sedangkan tujuan dari sistem kompensasi menurut Sedarmayanti dalam (Alini, 2015) adalah: (1). Menghargai kinerja; (2). Menjamin keadilan; (3). Mempertahankan karyawan (meningkatkan kepuasan dan mengurangi stres); (4). Memperoleh karyawan bermutu (5). 
Mengendalikan biaya; (6). Memenuhi peraturan. Berdasarkan seluruh penjelasan tersebut maka diduga terdapat pengaruh kompensasi terhadap stres kerja karyawan.

Menurut Musyafi', Utami, \& Mayowan (2016) dimensi kompensasi terdiri atas kompensasi fianansial dan non finansial. Kompensasi finansial indikatornya adalah gaji dan insentif sedangkan non finansial indikatornya adalah pekerjaan itu sendiri dan lingkungan. Pekerjaan itu sendiri dapat berupa jenjang karir yang pasti, penghargaan terhadap prestasi kerja, dan flexibilitas waktu bekerja.

\section{Lingkungan Kerja}

Lingkungan kerja adalah segala sesuatu (fisik dan non fisik) yang ada di sekitar para karyawan yang dapat mempengaruhi dirinya dalam menjalankan tugas dan tanggungjawab yang dibebankan (Nurhayati, Minarsih, \& Wulan, 2016). Hal ini mengakibatkan lingkungan atau tempat kerja dapat menyebabkan stres kerja. Work environment fit approach considers that "employee feels job stress when they have poor fit with the working environment (Singh \& Nayak, 2015). Lingkungan kerja yang nyaman mengakibatkan pegawai akan semangat untuk bekerja dan sebaliknya, lingkungan kerja yang tidak memuaskan dapat menurunkan semangat kerja dan akhirnya menurunkan produktifitas kerja pegawai serta dapat memicu stres kerja (Ahyari dalam Dhermawa et al., 2012).

Temuan tersebut diperkuat oleh N. Anderson et al., (2012) Decrying "the lack of generally accepted definitions of stress and strain in the work place. Lingkungan kerja sangat erat kaitannya dengan stres kerja. Hal tersebut diperkuat oleh Cox dalam N. Anderson et al., (2012) "has likened this approach to an engineering model in which environmental demands may put people under pressure and can physiological and psychological harm".

Lingkungan kerja yang kondusif, akan membentuk karyawan terkait sifat dan perilakunya. Lingkungan kerja fisik dapat merubah dan membentuk prilaku karyawan yang terdapat di dalamnya karena adanya interaksi dan usaha bertahan dalam lingkungan tersebut (Putra \& Subudi, 2015). Stress as a state of tension experienced by individuals facing extraordinary demands, constraints, or opportunities. As we show, stress can be both positive and negative and is an important fact of life in our present work environment (John R. Schermerhorn, Hunt, Osborn, \& Uhl-Bien, 2010).

Menurut Wursanto dalam Diah Indriani Suwondo \& Sutanto (2015), dimensi lingkungan kerja terdiri atas dua jenis. Pertama, lingkungan kerja yang di dalamnya termasuk segi fisik. Kedua, lingkungan kerja kaitannya dengan segi psikis tidak dapat ditangkap dengan panca indera. Dimensi tersebut kemudian dijabarkan oleh para ahli menjadi indicator-indikator pengukuran lingkungan kerja. Menurut Arianto, lingkungan kerja mempunyai beberapa indikator, seperti pewarnaan, penerangan kebersihan, musik pertukaran udara, keamanan dan kebisingan (Arianto, 2013).

\section{METHODS}

Penelitian ini menggunakan pendekatan kuantitatif dengan metode survey karena penelitian ini berusaha mengetahui pengaruh variable bebas terhadap variable terikat (Hendro Prasetyono, Abdillah, \& Fitria, 2018). Populasi penelitian ini adalah guru Sekolah Menengah Kejuruan Negeri (SMKN) di Jakarta Timur, yaitu SMKN 58, SMKN 51, SMKN 24 dan SMKN 52 sejumlah 162 orang. Penentuan sampel dihitung menggunakan rumus Slovin dengan toleransi 5\% didapatkan hasil 115 responden. Penelitian dilakukan selama bulan Agustus sampai Desember 2020 menggunakan googleform dalam penyebaran kuesioner. Teknik pengambilan sampel menggunakan 
simple random sampling karena tidak ada pertimbangan khusus dalam pemilihan sampel dan jumlah guru dianggap homogen sehingga diambil secara acak (Nurfarhana, Abdillah, \& Prasetyono, 2017).

Instrumen variable konsep diri pengambilan data menggunakan kuesioner dengan kisi-kisi yang dikembangkan dari indikator variabel yang tersaji pada table berikut:

Tabel 1.

Kisi-kisi Instrumen

\begin{tabular}{|c|c|c|c|}
\hline No. & Variabel & Dimensi & Jumlah \\
\hline 1. & Kompensasi $\left(\mathrm{X}_{1}\right)$ & $\begin{array}{l}\text { 1) Kompensasi finansial } \\
\text { 2) Kompensasi non finansial }\end{array}$ & 14 \\
\hline 2. & $\begin{array}{c}\text { Lingkungan } \\
\text { Kerja }\left(\mathrm{X}_{2}\right)\end{array}$ & $\begin{array}{l}\text { 1) Lingkungan kerja fisik } \\
\text { 2) Lingkungan kerja non fisik }\end{array}$ & 13 \\
\hline 3 & Stres Kerja (Y) & $\begin{array}{ll}\text { 1) } & \text { Luar organisasi } \\
\text { 2) } & \text { Organisasi } \\
\text { 3) } & \text { Kelompok } \\
\text { 4) } & \text { Individu } \\
\end{array}$ & 15 \\
\hline & \multicolumn{2}{|r|}{ Jumlah soal } & 42 \\
\hline
\end{tabular}

Sumber: Peneliti (2021)

Berdasarkan kisi-kisi instrument tersebut disusun 42 butir pernyataan dalam bentuk kuesioner. 42 pernyataan tersebut diuji valiliditasnya kepada 20 responden dan terdapat 11 butir item yang tidak valid karena nilai $r_{\text {hitung }}$ dibawah 0,44 . Sehingga 31 butir item yang valid diuji reliabilitas dan didapatkan koefisien $r_{11}$ sebesar 0,876 yang berarti sangat reliabel. Teknik analisis data dengan pendekatan kuantitatif diawali analisis korelasi, regresi linear sederhana dan uji hipotesis (H. Prasetyono, Abdillah, Widiarto, \& Sriyono, 2018). Hipotesis dalam penelitian ini, yaitu:

$\mathbf{H}_{\mathbf{1}}$ : Pengaruh kompensasi terhadap stress kerja

$\mathbf{H}_{2}$ : Pengaruh lingkungan kerja terhadap stress kerja

$\mathbf{H}_{3}$ : Pengaruh kompensasi dan lingkungan kerja terhadap stres kerja

\section{RESULTS \& DISCUSSION}

\section{Results}

Analisis regresi digunakan dalam membangun model persamaan regresi yang berfungsi untuk memprediksi pengaruh dan kontribusi variabel terikat secara parsial maupun Bersama-sama terhadap variabel terikat:

\section{Uji Regresi Linear Berganda}

Uji regresi linier berganda bertujuan untuk mengetahui besarnya pengaruh variabel bebas $(\mathrm{X})$ terhadap variabel terikat $(\mathrm{Y})$ secara simultan. Hasil penghitungan menggunakan SPSS 24 disajikan pada tabel berikut:

Tabel 2.

Hasil Penghitungan Regresi Berganda

\begin{tabular}{|c|c|c|c|c|c|}
\hline \multirow{2}{*}{ Model } & \multicolumn{2}{|c|}{ Unstandardized Coefficients } & \multirow{2}{*}{$\begin{array}{c}\text { Standardized } \\
\text { Coefficients } \\
\text { Beta } \\
\end{array}$} & \multirow{2}{*}{$\mathbf{t}$} & \multirow{2}{*}{ Sig. } \\
\hline & B & Std. Error & & & \\
\hline (Constant) & 18,663 & 3,131 & & 5,961 & 000 \\
\hline
\end{tabular}




\begin{tabular}{llllll}
\hline Kompensasi &, 429 &, 075 &, 446 & 5,757 & 000 \\
\hline Lingkungan Kerja &, 245 &, 060 &, 319 & 4,113 & 000 \\
\hline Sumber: Peneliti (2020) & & & &
\end{tabular}

Hasil uji koefisien regresi berganda pada tabel 2 tersebut pada bagian kolom konstanta 18,663, pada kolom Kompensasi nilai B sebesar 0,429 dan nilai t hitung sebesar 5,757 dengan nilai Sig 0,000. Sedangkan pada kolom Lingkungan Kerja didapatkan nilai $\mathrm{B}$ sebesar 0,245 dan nilai t hitung sebesar 4,113 dengan nilai sig 0,000. Maka didapatkan persamaan regresi adalah $\hat{Y}=18,663+0,429 X_{1}+0,245$ $\mathrm{X}_{2}$. Berdasarkan persamaan tersebut memiliki makna jika Setiap peningkatan satu unit variabel kompensasi maka akan meningkatkan variabel stres kerja sebesar 0,42 dan setiap kenaikan satu unit variabel lingkungan kerja akan meningkatkan variabel Y sebesar 0,245. Tetapi, jika tidak ada variabel kompensasi dan lingkungan kerja maka variabel stres kerja akan tetap sebesar 18,663.

\section{Korelasi Person}

Korelasi person digunakan untuk mengetahui hubungan variabel bebas secara parsial terhadap variabel terikat. Hasil penghitungan koefisien korelasi Person menggunakan software SPSS 24 tersaji pada tabel 3 berikut:

Tabel 3.

Hasil Penghitungan Korelasi Person

\begin{tabular}{llc|c|c}
\hline & & Stres Kerja & Kompensasi & Lingkungan Kerja \\
\hline Pearson Correlation & Stres Kerja & 1,000 &, 535 &, 444 \\
\cline { 2 - 5 } & Kompensasi &, 535 & 1,000 &, 280 \\
\cline { 2 - 5 } & Lingkungan Kerja &, 444 &, 280 & 1,000 \\
\hline \multirow{2}{*}{ Sig. (1-tailed) } & Stres Kerja &. &, 000 &, 000 \\
\cline { 2 - 5 } & Kompensasi &, 000 &. &, 001 \\
\cline { 2 - 5 } & Lingkungan Kerja &, 000 &, 001 & \multicolumn{1}{c}{115} \\
\hline \multirow{2}{*}{$\mathrm{N}$} & Stres Kerja & 115 & 115 & 115 \\
\cline { 2 - 5 } & Kompensasi & 115 & 115 & 115 \\
\cline { 2 - 5 } & Lingkungan Kerja & 115 & 115 & \\
\hline
\end{tabular}

Sumber: Peneliti (2020)

Berdasarkan tabel 3 tersebut di ketahui koefisien korelasi person hubungan Kompensasi $\left(\mathrm{X}_{1}\right)$ terhadap Stres Kerja $(\mathrm{Y})$ sebesar 0,535 yang berarti positif dan sedang. Hubungan antara lingkungan kerja $\left(\mathrm{X}_{2}\right)$ terhadap Stres Kerja $(\mathrm{Y})$ sebesar 0,444 yang berarti positif dan sedang. Hasil pengujian hipotesis sebagai berikut:

$\mathbf{H}_{\mathbf{1}}$ : Pengaruh kompensasi terhadap stres

Uji signifikansi pengaruh variabel bebas terhadap variabel terikat dengan cara membandingkan antara nilai probabilitas 0,05 dengan nilai sig. Kriteria pengujian adalah jika nilai probabilitas $0,05 \leq$ nilai sig maka Ho diterima dan Ha ditolak yang berarti tidak signifikan. Sedangkan jika nilai probabilitas $0,05 \geq$ nilai sig maka Ha diterima dan Ho ditolak yang berarti signifikan. Terlihat bahwa pada kolom sig. tabel 2 terdapat nilai Sig untuk Variabel Kompensasi adalah 0,000 yang berarti lebih kecil dari nilai probabilitas 0,05 atau nilai 0,05 > 0,000. Maka Ho ditolak dan Ha diterima. Hal ini berarti pengaruh Kompensasi terhadap Stres kerja adalah positif dan signifikan. 


\section{$\mathbf{H}_{2}$ : Pengaruh lingkungan kerja terhadap stres kerja}

Uji secara parsial ditunjukkan oleh tabel 2 terlihat hasil koefisien beta untuk variabel kompensasi terhadap stres kerja sebesar 0,319. Uji signifikansi pengaruh variabel bebas terhadap variabel terikat dengan cara membandingkan antara nilai probabilitas 0,05 dengan nilai sig. Kriteria pengujian adalah jika nilai probabilitas $0,05 \leq$ nilai sig maka Ho diterima dan Ha ditolak yang berarti tidak signifikan. Sedangkan jika nilai probabilitas $0,05 \geq$ nilai sig maka Ha diterima dan Ho ditolak yang berarti signifikan. Terlihat bahwa pada kolom sig. tabel 2 terdapat nilai Sig untuk Variabel Lingkungan Kerja adalah 0,000 yang berarti lebih kecil dari nilai probabilitas 0,05 atau nilai 0,05 > 0,000. Maka Ho ditolak dan Ha diterima. Hal ini berarti pengaruh Lingkungan Kerja terhadap Stres kerja adalah positif dan signifikan.

\section{Uji F}

Pada penelitian ini, uji $\mathrm{F}$ dilakukan untuk menguji hipotesis ketiga yang berbunyi kompensasi $\left(\mathrm{X}_{1}\right)$ dan lingkungan kerja $\left(\mathrm{X}_{2}\right)$ secara bersama-sama berpengaruh signifikan terhadap Stres kerja (Y). Hasil penghitungan menggunakan software SPSS tersaji pada tabel berikut:

Tabel 4.

Hasil Penghitungan Uji F

\begin{tabular}{cccc|c|c|c}
\hline & Model & Sum of Squares & df & Mean Square & F & Sig. \\
\hline \multirow{2}{*}{1} & Regression & 1272,855 & 2 & 636,428 & 34,348 &, 000 \\
\cline { 2 - 7 } & Residual & 2075,232 & 112 & 18,529 & & \\
\cline { 2 - 8 } & Total & 3348,087 & 114 & & & \\
\hline \multicolumn{2}{l}{ Sumber: Peneliti (2020) } & & & &
\end{tabular}

Berdasarkan tabel 4 tersebut diketahui bahwa nilai $\mathrm{F}$ hitung sebesar 34,348 dan nilai Sig adalah 0,000. Hal ini berarti nilai Sig lebih kecil dari 0,005 atau 0,05 > 0,000 maka dapat disimpulkan jika Variabel Kompensasi dan Lingkungan Kerja secara bersama-sama berpengaruh positif dan signifikan terhadap Variabel Stres Kerja.

\section{Koefisien Determinasi (Adjusted $\mathbf{R}^{2}$ )}

Nilai koefisien determinasi menjelaskan kontribusi variabel bebas terhadap variabel terikat. Semakin tinggi nilai koefisien determinasi maka akan semakin baik juga kemampuan variabel bebas dalam menjelaskan variabel terikat. Koefisien determinasi didapatkan dari hasil pengkuadratan koefisien korelasi setiap variabel bebas dengan variabel terikat dikalikan $100 \%$.

a. Koefisien Determinasi Variabel Kompensasi terhadap Stres Kerja

Berdasarkan tabel 4.11 tersebut diketahui koefisien Korelasi Person Variabel Kompensasi terhadap Stres kerja sebesar 0,535 maka nilai koefisien determinasi adalah $0,535^{2} \times 100 \%=0,286 \times 100 \%=28,6 \%$.

b. Koefisien Determinasi Variabel Lingkungan Kerja terhadap Stres Kerja

Berdasarkan tabel 4.11 tersebut diketahui koefisien Korelasi Person Variabel Lingkungan Kerja terhadap Stres kerja sebesar 0,444 maka nilai koefisien determinasi adalah $0,444^{2} \times 100 \%=0,197 \times 100 \%=19,7 \%$.

c. Koefisien Determinasi Variabel Kompensasi dan Lingkungan Kerja secara Bersama-sama terhadap Stres Kerja

Hasil penghitungan Koefisien Determinasi Variabel Kompensasi dan Lingkungan Kerja tersaji pada tabel 5 sebagai berikut: 
Tabel 5.

Hasil Penghitungan Koefisien Determinasi

\begin{tabular}{cc|c|c|c|c|c|c|c|c}
\hline Model & \multirow{2}{*}{ R } & \multirow{2}{*}{ R Square } & $\begin{array}{c}\text { Adjusted } \\
\text { R Square }\end{array}$ & $\begin{array}{c}\text { Std. Error of } \\
\text { the Estimate }\end{array}$ & $\begin{array}{c}\text { R Square } \\
\text { Change }\end{array}$ & $\begin{array}{c}\text { F } \\
\text { Change }\end{array}$ & df1 & df2 & $\begin{array}{c}\text { Sig. F } \\
\text { Change }\end{array}$ \\
\hline 1 &, $617^{\mathrm{a}}$ &, 380 &, 369 & 4,305 &, 380 & 34,348 & 2 & 112 &, 000 \\
\hline
\end{tabular}

Sumber: Peneliti (2020)

Berdasarkan tabel 5 tersebut diketahui nilai R Square sebesar 0,380 maka nilai koefisien determinasi adalah $0,380 \times 100 \%=38 \%$. Hal ini berarti total kontribusi Variabel Kompensasi dan Lingkungan Kerja terhadap Stres Kerja adalah 38\%. Sisanya sebesar $62 \%$ dipengaruhi oleh variabel lain yang tidak diteliti dalam penelitian ini.

\section{Discussion}

\section{Pengaruh Secara Bersama-Sama Kompensasi dan Lingkungan Kerja Tehadap Stress Kerja}

Hasil pengujian hipotesis 1 didapatkan temuan kompensasi memiliki pengaruh yang positif dan signifikan terhadap stress kerja karyawan. Hal ini berarti semakin tinggi kompensasi yang didapatkan akan mengakibatkan semakin tinggi pula tingkat stress yang alami oleh guru SMKN. Sedangkan angka koefisien korelasi sebesar 0,535 yang berarti kompensasi memiliki hubungan positif dan berada dalam kategori sedang dengan stress kerja. Hasil ini makin menguatkan hasil penelitian sebelumnya yang memiliki kesimpulan bahwa kompensasi memiliki pengaruh positif dan signifikan terhadap stress kerja (Febriana, 2013).

Temuan ini menjadi menarik karena seharusnya jika analisis secara sederhana apabila seorang guru yang memiliki kompensasi tinggi akan merasa lebih gembira karena mendapatkan kompensasi berupa finansial dan non finansial lebih banyak guna memenuhi kebutuhan hidupnya sehingga dapat mengurangi resiko munculnya stress (Niu et al., 2018). Kompensasi pada beberapa penelitian lain menunjukkan hasil berpengaruh terhadap kepuasan pegawai dalam bekerja, kinerja meningkat dan akan lebih komitmen terhadap organisasi tempat bekerja (Alini, 2015; Handaru et al., 2013; Sari, 2009).

\section{Pengaruh Kompensasi Terhadap Stress Kerja}

Temuan unik ini dapat dijelaskan oleh Nasution (2017) menyatakan bahwa stres disebabkan karena berlebihannya beban kerja, perusahaan memberi tekanan yang tinggi, target tidak terpenuhi, dan kurang konsentrasi dalam bekerja. Seorang guru SMKN pada dasarnya adalah seorang guru yang tugas utamanya adalah mengajar selama pandemi Covid-19 yang serba memiliki keterbatasan. Seorang guru memiliki target kerja setiap bulan dalam mengajar berkorelasi positif dengan kompensasi yang didapatkan.

Namun stres kerja pada temuan dalam penelitian tidak selamanya memiliki dampak yang negative. Stres kerja diartika sebagai kondisi yang dirasakan menekan atau merasa tertekan yang dialami pegawai dalam menghadapi pekerjaan (Wisantyo \& Madiistriyatno, 2015). Stres ternyata memiliki dampak yang positif dan dapat memicu kinerja karena para pegawai memiliki perasaan tertekan dalam menghadapi pekerjaan. Hal tersebut dijelaskan bahwa dampak dari stres terbagi atas 2 jenis, yaitu Eustress is a stress that has a positive impact on both attitudes and performance dan Distress is a negative impact on both attitudes and performance (John R. Schermerhorn et al., 2010). Sehingga stres kerja yang muncul pada guru SMKN berdampak positif dalam 
memotivasi para guru untuk bekerja sesuai dengan target yang dipicu oleh keinginan untuk mendapatkan kompensasi yang tinggi.

Hasil pengujian hipotesis 2 didapatkan temuan lingkungan kerja memiliki pengaruh yang positif dan signifikan terhadap stress kerja karyawan. Hal ini berarti lingkungan kerja dapat memicu secara langsung menimbulkan stres kerja dikalangan guru. Sedangkan angka koefisien korelasi sebesar 0,444 yang berarti Lingkungan Kerja memiliki hubungan positif dan berada dalam kategori sedang dengan stress kerja. Hasil penelitian ini makin menguatkan hasil-hasil penelitian sebelumnya yang menyatakan lingkungan kerja berpengaruh positif dan signifikan terhadap stres kerja karyawan (Susilo, 2013; Musliha Fitri, 2013).

Jika merujuk kepada grand theory dari stres kerja, lingkungan kerja dapat memicu secara langsung puas atau tidak puasnya pegawai dalam bekerja (Sudiardhita, Baqi, \& Handaru, 2016). Lingkungan kerja yang tidak sesuai dengan harapan pegawai (tidak kondusif atau selalu berubah-ubah) sehingga memicu tidak puasnya pegawai yang jika dibiarkan dapat memicu stres kerja. Hal ini yang menurut Hurrel dalam Putranto (2013) menyatakan hubungan dalam pekerjaan merupakan salah satu jenis dari indikator lingkungan sosial dalam dimensi lingkungan kerja.

Pendapat lain menurut Nur (2013) terdapat 2 dimensi pengukuran stres kerja yang salah satunya disebut perceived environmental stressor atau demands adalah tuntutan lingkungan. Lingkungan kerja merujuk kepada hal-hal yang terkait dengan struktur tugas, desain pekerjaan, imbalan, gaya kepemimpinan, sarana dan prasarana, dan jaringan kerjasama (Widodo, 2010). Gibson et al., (2012) menyatakan lingkungan kerja butuh perhatian ekstra agar dapat mengamati apa yang menjadi penyebab munculnya stres kerja pegawai. Menurut Luthans (2011) menyatakan bahwa lingkungan kerja termasuk ke dalam dimensi dari stres pada kategori yang berasal dari organisasi. Lingkungan kerja yang nyaman mengakibatkan pegawai akan semangat untuk bekerja dan sebaliknya, lingkungan kerja yang tidak memuaskan dapat menurunkan semangat kerja dan akhirnya menurunkan produktifitas kerja pegawai serta dapat memicu stres kerja (Ahyari dalam Dhermawa et al., 2012). Kesesuaian lingkungan kerja dapat dilihat akibatnya dalam jangka waktu yang lama. Kondisi lingkungan kerja yang kurang kondusif membuat tenaga kerja akan ada tuntutan dan memerlukan waktu lebih sehingga kurang mendukung efisiensi sistem kerja (Alif, 2015).

Hasil pengujian hipotesis 3 didapatkan temuan kompensasi dan lingkungan kerja memiliki pengaruh yang positif dan signifikan terhadap stress kerja karyawan dengan kontribusi sebesar 38\%. Hal ini berarti kompensasi dan lingkungan kerja secara langsung menimbulkan stres kerja dikalangan guru SMKN. Hasil penelitian ini melengkapi hasil-hasil penelitian sebelumnya yang secara parsial menyimpulkan kompensasi dan lingkungan kerja berpengaruh positif dan signifikan terhadap stres kerja karyawan (Febriana, 2013; Susilo, 2013; Musliha Fitri, 2013).

$\mathrm{N}$. Anderson et al., (2012) yang menyatakan occupational stress is a growing problem that results in substantial cost to individual employees and work organizations around the globe. Jadi stres kerja tumbuh karena permasalahan antara gaji (pembiayaan) yang diterima oleh pegawai dengan tuntutan yang diberikan oleh organisasi terhadap pegawai tersebut. Tuntutan yang diberikan oleh organisasi merupakan salah satu bentuk dari dimensi lingkungan sosial pada variabel lingkungan kerja. Sehingga lingkungan kerja dan kompensasi secara bersama-sama berpengaruh terhadap stres kerja pegawai.

\section{Pengaruh Lingkungan Kerja Terhadap Stress Kerja}

Lingkungan pekerjaan fisik dan non fisik yang kurang nyaman mengakibatkan semangat berkerja karyawan semakin menurun; sehingga tingkat produktifitas karyawan juga semakin menurun yang jika ketiga dampak ini tidak diperbaiki dapat 
menimbulkan stres kerja (Susilo, 2013). Luthans (2011) menyatakan kompensasi dan lingkungan kerja merupakan indikator dalam dimensi dari stress kerja yang dijabarkan menjadi (1) Extraorganizational Stressors adalah stress yang berasal dari luar organsiasi yang mempengaruhi kinerja karyawan yang terdiri atas perubahan teknologi, globalisasi, keluarga, pindah tugas, kondisi ekonomi dan finansial, suku dan ras, kondisi tempat tinggal; (2) Organizational Stressors, stress yang berasal dari dalam organisasi terkait dengan tugas dan tanggungjawab karyawan yang terdiri atas indikator tugas dikantor, konflik dan beban kerja, keamanan kerja, konflik sesama rekan kerja, lingkungan yang tidak menentu. Sehingga dapat disimpulkan jika lingkungan kerja yang kondusif dapat mengurangi stres kerja guru.

\section{CONCLUSION}

Terdapat pengaruh kompensasi terhadap stress kerja; terdapat pengaruh lingkungan kerja terhadap stress kerja; secara simultan terdapat pengaruh kompensasi dan lingkungan kerja terhadap stress kerja. Kompensasi memiliki kontribusi lebih besar jika dibandingkan dengan lingkungan kerja. Implikasinya pihak manajemen sekolah harus tetap menjadi kompensasi yang layak bagi para guru dan menciptakan lingkungan kerja mulai mengadopsi teknologi untuk mengurangi stress kerja guru di masa Pandemi Covid-19.

\section{REFERENCES}

Alif, A. (2015). Pengaruh Motivasi Kerja, Pengembangan Karir Dan Lingkungan Kerja Terhadap Organizational Citizenship Behavior (Ocb) Dengan Kepuasan Kerja Sebagai Variabel Intervening Pada Perusahaan Terminal Lpg. Jurnal MIX, VI(2), 291-309.

Alini. (2015). Pengaruh Kompensasi Terhadap Kinerja Karyawan ( Studi Pada Hotel Kartika Chandra Jakarta ). E-Proceeding of Management Vol.2 No.1 April 2015, 671, 2(1), 671-685.

Anderson, L., Mason, K., Hibbert, P., \& Rivers, C. (2017). Management education in turbulent times. Journal of Management Education, 41(2), 303-306. https://doi.org/10.1177/1052562916682208

Anderson, N., Ones, D. S., Sinangil, H. K., \& Viswesvaran, C. (2012). Handbook of Industrial, Work \& Organizational Psychology (Vol. 2). https://doi.org/10.4135/9781848608368.n11

Ansley, B. M., Houchins, D. E., Varjas, K., Roach, A., Patterson, D., \& Hendrick, R. (2021). The impact of an online stress intervention on burnout and teacher efficacy. Teaching and Teacher Education, 98, 103251. https://doi.org/10.1016/j.tate.2020.103251

Cappe, E., Poirier, N., Engelberg, A., \& Boujut, E. (2021). Comparison of teachers in France and in Quebec working with autistic students: Self-efficacy, stress, social support, coping, and burnout. Teaching and Teacher Education, 98, 103244. https://doi.org/10.1016/j.tate.2020.103244

Chaturvedi, K., Kumar Vishwakarma, D., \& Nidhi. (2020). COVID-19 and its impact on education, social life and mental health of students: A Survey. Children and Youth $\begin{array}{llll}\text { Services } & \text { Review, } & 121 \text { (July 2020), }\end{array}$ https://doi.org/10.1016/j.childyouth.2020.105866

Daft, R. L. (2008). Management (Eighth). Mason: Thomson South-Western.

Dhermawa, A. A. N. B., Sudibya, I. G. A., \& Utama, I. W. M. (2012). Pengaruh 
Motivasi, Lingkungan Kerja, Kompetensi, Dan Kompensasi Terhadap Kepuasan Kerja Dan Kinerja Pegawai Di Lingkungan Kantor Dinas Pekerjaan Umum Provinsi Bali. Jurnal Manajemen, Strategi Bisnis, Dan Kewirausahaan, 6(2), 173184.

Febriana, S. K. T. (2013). Faktor-Faktor yang Mempengaruhi Stres Kerja. Jurnal Ecopsy, 1(1), 28-32. Retrieved from http://download.portalgaruda.org/article.php?article $=137291 \& \mathrm{val}=5064$

Gibson, J. L., Ivancevich, J. M., James H. Donnelly, J., \& Konopaske, R. (2012). Organizations Behavior, Structure, Processes.

Handaru, A. W., Utomo, T., \& Sudiarditha, I. K. R. (2013). Pengaruh Lingkungan Kerja, Kompensasi Dan Komitmen Organisasi Terhadap Kepuasan Kerja Karyawan DI RS “X.” Jurnal Riset Manajemen Sains Indonesia (JRMSI), 4(1), 116-135.

Hussain, A., \& Chaman, S. (2016). Combined Effect of Personality Traits and Collectivistic Culture on Employee'S Job Stress in Banking Sector. International Journal of Arts \& Sciences, 9(3), 311-324. Retrieved from http://search.proquest.com.ezproxy.saintleo.edu/docview/1858849712?accountid=4 870

Irawati, A. (2018). Pengaruh Stres Kerja, Motivasi Kerja, Kompensasi terhadap Kinerja Karyawan Dengan Lama Kerja Sebagai Variabel Moderating. Akuntabilitas: Jurnal Ilmu Akuntansi, 11(1), 117-134. https://doi.org/10.15408/akt.v11i1.8789

John R. Schermerhorn, J., Hunt, J. G., Osborn, R. N., \& Uhl-Bien, M. (2010). Organizational Behavior. Denvers: John Wiley \& Sons, Inc.

Luthans, F. (2011). Organizational Behavior An Evidence-Based Approach. In McGrawHill/Irwin (12th ed.). New York: The McGraw-Hill Companies, Inc.

Macintyre, P. D., Ross, J., Talbot, K., Mercer, S., Gregersen, T., \& Ann, C. (2019). Stressors, personality and wellbeing among language teachers. System, 82, 26-38. https://doi.org/10.1016/j.system.2019.02.013

Musliha Fitri, A. (2013). Analisis Faktor-faktor yang Berhubungan dengan Kejadian Stres Kerja pada Karyawan Bank (Studi pada Karyawan Bank Bmt). Jurnal Kesehatan Masyarakat, 2(1), 1-10.

Nasution, M. I. (2017). Pengaruh Stres Kerja, Kepuasan Kerja Dan Komitmen Organisasi Terhadap Turnover Intention Medical Representative. MIX: Jurnal Ilmiah Manajemen, VII(3), 407-428.

Niu, J., Zhang, S., Liu, S., Ma, H., Chen, J., Shen, Q., ... Zhao, X. (2018). The compensation effects of physiology and yield in cotton after drought stress. Journal of Plant Physiology, 224-225(November 2017), 30-48. https://doi.org/10.1016/j.jplph.2018.03.001

Nur, S. (2013). Konflik, stres kerja dan kepuasan kerja pengaruhnya terhadap kinerja pegawai pada Universitas Khairun Ternate. Jurnal EMBA, 1(3), 739-749.

Nurfarhana, A., Abdillah, A., \& Prasetyono, H. (2017). Faktor Yang Berpengaruh Terhadap Disiplin Kerja Guru SMKN 1 Depok Dan SMKS Yapan Indonesia. Jurnal Research and Development Journal Of Education, 44(22), 3-22.

Nurhayati, D., Minarsih, M. M., \& Wulan, H. S. (2016). Pengaruh Kepuasan Kerja, Lingkungan Kerja Dan Loyalitas Kerja Tehadap Organizational Citizenship Behavior (OCB) ( Studi Kasus Pada PT. Perwirabhakti Sentrasejahtera Di Kota Semarang). Journal of Management, 2(2), 1-24.

Paramita, W., Putra, T. E., \& Handaru, A. W. (2016). The Influence of Job Stress and Job Statisfaction on Employee'S Organizational Commitment At CV. Dipo Production. Jurnal Riset Manajemen Sains Indonesia, 7(2), 303-324. https://doi.org/10.21009/jrmsi.007.2.06

Powell, M. B., Guadagno, B. L., \& Cassematis, P. (2013). Workplace stressors for 
investigative interviewers of child-abuse victims. Policing, 36(3), 512-525. https://doi.org/10.1108/PIJPSM-05-2012-0039

Prasetyono, H., Abdillah, A., Widiarto, T., \& Sriyono, H. (2018). Character-based Economic Learning Implementation and Teacher's Reinforcement on Student's Affective Competence in Minimizing Hoax. Cakrawala Pendidikan, 37(3), 426435.

Prasetyono, Hendro, Abdillah, A., \& Fitria, D. (2018). Academic Supervision toward Teacher' s Performance through Motivation as Intervening Variable. Journal of Education and Learning (EduLearn), 12(2), 188-197. https://doi.org/10.11591/edulearn.v12i2.7324

Putra, I. K. A. P., \& Subudi, M. (2015). Pengaruh Gaya Kepemimpinan Transformasional Dan Lingkungan Kerja Fisik Terhadap Kinerja Karyawan PT BPR Pedungan. EJurnal Manajemen Unud, 4(10), 3146-3171.

Putranto, C. (2013). Faktor - Faktor Yang Mempengaruhi Stres Kerja : Studi Indigenous Pada Guru Bersuku Jawa. Journal of Social and Industrial Psychology, 2(2), 2833.

Ratten, V., \& Jones, P. (2020). Covid-19 and entrepreneurship education: Implications for advancing research and practice. International Journal of Management Education, (xxxx), 100432. https://doi.org/10.1016/j.ijme.2020.100432

Sari, E. (2009). Pengaruh Kompensasi dan Iklim Organisasi terhadap Kepuasan Kerja. Jurnal ILmu Aministrasi Dan Organisasi, 16(1), 18-24.

Singh, R., \& Nayak, J. K. (2015). Mediating role of stress between work-family conflict and job satisfaction among the police officials: Moderating role of social support. Policing: An International Journal of Police Strategies \& Management, 38(4), 738-753. https://doi.org/10.1108/PIJPSM-03-2015-0040

Sudiardhita, I. K. R., Baqi, F. H., \& Handaru, A. W. (2016). The Influence Of Job Stress And Compensation To Job Satisfaction At PT Tri Megah Makmur. Jurnal Riset Manajemen Sains Indonesia (JRMSI), 7(2), 219-240.

Sunarsi, D. (2018). Pengaruh Kompensasi, Komunikasi Dan Stress Kerja Terhadap Prestasi Kerja Karyawan Pada PT Catur Putra Jaya Kota Depok - Jawa Barat. JiIMF(Jurnal Ilmiah Manajemen Forkamma), 1(2), 113-127. https://doi.org/10.32493/frkm.v1i2.2543

Susilo, T. (2013). Analisis Pengaruh Faktor Lingkungan Fisik Dan Non Fisik Terhadap Stress Kerja Pada PT. Indo Bali Di Kecamatan Negara Kabupaten Jimbaran Bali. Journal of Chemical Information and Modeling, 53(9), 1689-1699. https://doi.org/10.1017/CBO9781107415324.004

Vertanen-Greis, H., Loyttyniemi, E., Uitti, J., \& Putus, T. (2020). Work ability of teachers associated with voice disorders, stress, and the indoor environment: A questionnaire study in Finland. Journal of Voice. https://doi.org/10.1016/j.jvoice.2020.09.022

Widodo, T. (2010). Pengaruh Lingkungan Kerja, Budaya Organisasi, Kepemimpinan Terhadap Kinerja (Studi pada Pegawai Kecamatan Sidorejo Kota Salatiga). Jurnal Among Makarti, 3(5), 14-35.

Wisantyo, \& Madiistriyatno. (2015). Pengaruh Stres Kerja, Disiplin Kerja Dan Kepuasan Kerja Terhadap Intensi Turnover. Jurnal MIX, V(1), 54-69. 